\title{
Ectoparasitic species of the genus Trichodina (Ciliophora: Peritrichida) parasitizing Macedonian freshwater fish
}

\author{
DIJANA BLAZHEKOVIKJ-DIMOVSKA, ${ }^{1}$ STOJMIR STOJANOVSKI ${ }^{2}$ \\ ${ }^{1}$ University “St. Kliment Ohridski”, Faculty of Biotechnical Sciences, Bitola, N. Macedonia, ORCID: 0000-0001-5912-9093 \\ ${ }^{2}$ Hidrobiological Institute, Laboratory of fish diseases, Ohrid, N. Macedonia, ORCID: 0000-0003-4704-4820 \\ Corresponding author e-mail: dijanablazekovic@yahoo.com
}

Keywords protozoa, Trichodina sp., grass carp, common carp, aquaculture

Abstract Trichodinids are probably the most commonly encountered protozoan parasites on fishes in marine and freshwater environments. They are typically found on the gills, skin and fins of fish. The aim of this study was to evaluate the prevalence and mean intensity of Trichodina sp. in freshwater fish from cyprinid aquaculture facilities in Macedonia. This study was carried out by seasons, in a period of three years. A total of 578 specimens of common carp (Cyprinus carpio, Linnaeus 1758), 76 specimens of grass carp (Ctenopharyngodon idella, Valenciennes 1844), 47 specimens of silver carp (Hypophthalmichthys molitrix, Valenciennes, 1844) and 53 specimens of bighead carp (Hypophthalmichthys nobilis, Richardson, 1845) from the most significant and larger cyprinid aquaculture facilities in Macedonia, including fish farms and reservoirs, were examined for parasitological investigations. Infestation with Trichodina sp. was found in 206 specimens of common carp in all aquaculture facilities examined, in all seasons, as well as, in 9 specimens of grass carp from two fish farms, only in autumn season. Total, the prevalence with Trichodina sp. was $11.84 \%$ (grass carp) and $35.67 \%$ (common carp), while the, mean intensity was 7.56 (grass carp) and 4.56 (common carp). The prevalence with Trichodina sp. in common carp by season was as following: spring $-11.82 \%$, summer $-3.44 \%$, autumn $-7.85 \%$, winter $-7.05 \%$, while the mean intensity was: spring -4.55 ; summer -4.67 ; autumn -4.40 ; winter -4.72 . Our findings of Trichodina sp. in grass carp in the present study is considered as the first record in Macedonia. Also, this fish species is regarded as new host for Trichodina sp. in Macedonian waters.

\section{Pasożyty zewnętrzne ryb słodkowodnych Macedonii z rodziny Trichodina (Ciliophora: Peritrichida)}

Słowa kluczowe pierwotniaki, Trichodina sp., amur biały, karp, akwakultura

Streszczenie Trichodinidae są prawdopodobnie najczęściej spotykanymi pierwotniakami pasożytującymi na rybach słodkowodnych i morskich. Zazwyczaj spotykane są na skrzelach, skórze i płetwach ryb. Celem artykułu jest określenie częstotliwości i intensywności zarażenia ryb karpiowatych przez Trichodina sp. Badania trwały trzy lata. Łącznie przebadano pod kątem parazytologicznym 578 osobników karpia (Cyprinus carpio, Linnaeus 1758), 76 amurów białych 
(Ctenopharyngodon idella, Valenciennes 1844), 47 tołpyg białych (Hypophthalmichthys molitrix, Valenciennes, 1844) i 53 tołpyg pstrych (Hypophthalmichthys nobilis, Richardson, 1845). Zakażenie Trichodina sp. stwierdzono u 206 osobników karpia we wszystkich badanych stawach i okresach, oraz w okresie jesiennym u 9 amurów białych z dwóch stawów hodowlanych. Łącznie zarażonych Trichodina sp. było 11.84\% amurów białych oraz $35.67 \%$ karpi, średnia intensywność zarażenia amurów białych wynosiła 7.56, a w przypadku karpia - 4.56. W okresie wiosennym zarażonych było $11.82 \%$ karpi, latem $-3.44 \%$, jesienią $-7.85 \%$, a zimą $-7.05 \%$. Odpowiednio średnia intensywność zarażenia wynosiła wiosną - 4.55; latem - 4.67; jesienią - 4.40 I zimą - 4.72. Stwierdzenie Trichodina sp. pasożytującego na amurze białym jest pierwszym przypadkiem zaobserwowanym w Macedonii. W związku z tym gatunek ten jest nowym gospodarzem dla Trichodina sp. w wodach Macedonii.

\section{Introduction}

The largest genus of the family Trichodinidae is the genus Trichodina (Ehrenberg, 1838), ciliate protists well known as the causative agent of trichodiniasis in numerous aquatic animals (Marcotegui et al., 2018; Martins et al., 2015), with more than 200 species described from fish (Asmat et al., 2005). According Tang and Zhao (2011; 2012), to date about 300 nominal Trichodina species have been reported from different environments in the world.

Trichodinids are ciliate protozoans widely known as ectocommensals and are probably the most commonly encountered protozoan parasites on fishes in marine and freshwater environments (Martins, Ghiraldelli, 2008). According Huh et al. (2005) and Khan (2004) trichodina can serve as a facultative ecto-parasite and can proliferate and invade hosts during unfavorable conditions in environments, such as poor water quality and food deficiency. Lom (1995) concluded that the trichodinid are able to invade their hosts within a short period because of their direct transmission, especially fish with less condition. Lom and Dykova (1992) considered that the determination of Trichodina species is difficult because many species are morphologically variable and show low host specificity. In the taxonomy of trichodinids, the exact number, shape and arrangement of the cytoskeletal denticles is critical for determining taxonomic relationships. These characters are usually revealed by silver nitrate staining of microscope slides, which stains the cell cytoplasm black and leaves the denticles white. Trichodinids are best known as ecto-parasites of skin, fin and gill of the fish with most of the species reported from freshwater environments.

According to data from parasitological research in Macedonia, Hristovski et al. (2006; 2012) determined Trichodina sp. at common carp (Cyprinus carpio) from Prespa Lake, with a prevalence of $1.32 \%$. In addition, the same authors also established Trichodina sp. in Leuciscus cephalus prespensis. Chondrostoma nasus prespensis, Alburnus alburnus belvica and Rutilus rubilio prespensis from Prespa Lake.

According to literary reviews from the Balkan countries, Trichodina sp. at Cyprinus carpio in Bosnia and Herzegovina was first established by Žitnan et al. (1969) in the fish farming "Vučijak" - Prnjavor. Data on the presence of this parasite in waters in Serbia is published by Cakić (1992), while in Croatia, Tomec et al. (1995) in the fish farms "Narta" and "Blatnica" and Valić et al. (2005) in a fish population in the Krka River.

In the cyprinid fish farms in Romania, Trichodina sp. was established on gills of Cyprinus carpio by Lazar (2009), while on the fins, gills and body cavity by Radu et al. (2008). In the cyprinid fish farms in the Czech Republic, Ondračková et al. (2012) determined the presence of Trichodina sp. in two years old carp. In Turkey, data on the presence of Trichodina sp. at Cyprinus carpio in the Seyhan River was reported by Cengizler et al. (2001). 
According to literary reviews from the world, Ali et al. (1988) and Mansoor \& Al-Shaikh (2010) determined the presence of Trichodina domerguei in waters in Iraq, while Subasinghe (1992) established Trichodina sp. in juveniles and adult carp in cyprinid fish farms in Sri Lanka. Tantry et al. (2016) reported first findings of trichodinid fauna at Cyprinus carpio collected from various fish ponds and farms in Jammu division of Jammu and Kashmir state.

Regarding grass carp (Ctenopharyngodon idella), species of the genus Trichodina are identified by Ali et al. (1988) in fish farms in Iraq and Bozorgnia et al. (2012) in fish farms in Iran.

\section{Materials and methods}

The aim of this study was to evaluate the prevalence and mean intensity of Trichodina sp. in freshwater fish from cyprinid aquaculture facilities in Macedonia. This study was carried out by seasons, in a period of three years. A total of 578 specimens of common carp (Cyprinus carpio, Linnaeus 1758), 76 specimens of grass carp (Ctenopharyngodon idella, Valenciennes 1844), 47 specimens of silver carp (Hypophthalmichthys molitrix, Valenciennes, 1844) and 53 specimens of bighead carp (Hypophthalmichthys nobilis, Richardson, 1845) from the most significant and larger cyprinid aquaculture facilities in Macedonia, including fish farms and reservoirs, were examined for parasitological investigations. These aquaculture facilities included fish farms Zhabeni, Bukri, Dolneni and Zhelezara, as well as fish cage culture systems on reservoirs Tikvesh, Mladost, Globochica and Gradche. The specimens were placed in plastic containers and transferred alive to the laboratory.

Gills, fins and skin were examined using stereomicroscopes “Zeiss” - Stemi DV4 and „MBS 10", as well as microscopes "Zeiss" - PrimoVert and "Reichart" were used. All parasites found in each fish were identified and enumerated. Parasites on native smears were observed under a light microscope and magnification $\times 200$ and $\times 400$.

Classical epidemiological variables (prevalence and mean intensity) were calculated according to Bush et al. (1997).

The parasite specimens were identified using reference keys of Lom and Dykova (1992)

\section{Results and discussion}

A total of 578 specimens of common carp, 76 specimens of grass carp, 47 specimens of silver carp and 53 specimens of bighead carp from the most significant and larger cyprinid aquaculture facilities in Macedonia were examined for parasitological investigations. Infestation with Trichodina sp. was found in 206 specimens of common carp in all aquaculture facilities examined, in all seasons, as well as, in 9 specimens of grass carp from two fish farms, only in autumn, as following:

- on gills in common carp from fish farm Zhabeni, in summer and autumn,

- on gills in common carp from fish farm Bukri, in spring and summer,

- on fins in common carp from fish cage culture system on Tikvesh reservoir, in autumn,

- on gills in common carp from fish cage culture system on Mladost reservoir, in spring, autumn and winter,

- on fins and gills in common carp from fish cage culture system on Globochica reservoir, in spring and winter,

- on fins and gills in common carp from fish farm Dolneni, in autumn, 
- on gills and liver in common carp from fish cage culture system on Gradche reservoir, in spring and winter,

- on gills in common carp from from fish farm Zhelezara, in spring,

- on fins in grass carp from fish farm Zhabeni, in autumn,

- on gills in grass carp from fish farm Bukri, in autumn,

Data on fish examined, fish infected, as well as the prevalence and mean intensity with Trichodina sp., total and by seasons, are given in Table 1 and Table 2.

Table 1. Prevalence and mean intensity with Trichodina sp. in common carp (Cyprinus carpio) and grass carp (Ctenopharyngodon idella) from cyprinid aquaculture facilities in Macedonia

\begin{tabular}{|l|c|c|c|c|}
\hline \multicolumn{1}{|c|}{ Fish species } & $\begin{array}{c}\text { Number } \\
\text { of examined fish }\end{array}$ & $\begin{array}{c}\text { Number } \\
\text { of infected fish }\end{array}$ & $\begin{array}{c}\text { Mean } \\
\text { intensity }\end{array}$ & $\begin{array}{c}\text { Prevalence } \\
\text { (\%) }\end{array}$ \\
\hline $\begin{array}{l}\text { Common carp } \\
\text { (Cyprinus carpio) }\end{array}$ & 578 & 206 & 4.56 & 35.67 \\
\hline $\begin{array}{l}\text { Grass carp } \\
\text { (Ctenopharyngodon idella) }\end{array}$ & 76 & 9 & 7.56 & 11.84 \\
\hline
\end{tabular}

Table 2. Prevalence (E) and mean intensity (I) with Trichodina sp. in common carp (Cyprinus carpio) from cyprinid aquaculture facilities in Macedonia, by seasons

\begin{tabular}{|l|c|c|c|c|c|c|c|c|}
\hline \multirow{2}{*}{ Parasite species } & \multicolumn{2}{|c|}{ Spring } & \multicolumn{2}{c|}{ Summer } & \multicolumn{2}{c|}{ Autumn } & \multicolumn{2}{c|}{ Winter } \\
\cline { 2 - 9 } & $\mathrm{I}$ & $\mathrm{E}(\%)$ & $\mathrm{I}$ & $\mathrm{E}(\%)$ & $\mathrm{I}$ & $\mathrm{E}(\%)$ & $\mathrm{I}$ & $\mathrm{E}(\%)$ \\
\hline Trichodina sp. & 4.55 & 11.82 & 4.67 & 3.44 & 4.40 & 7.85 & 4.40 & 7.05 \\
\hline
\end{tabular}

Total, the prevalence with Trichodina sp. in common carp was $35.67 \%$, while the mean intensity 4.56 . The prevalence with Trichodina sp. in common carp by season was as following: spring $-11.82 \%$, summer $-3.44 \%$, autumn $-7.85 \%$, winter $-7.05 \%$, while the mean intensity was: spring -4.55 ; summer -4.67 ; autumn -4.40 ; winter -4.40 .

The prevalence with Trichodina sp. in grass carp was $11.84 \%$, while the mean intensity 7.56 .

Our findings of Trichodina sp. in grass carp in the present study is considered as the first record in Macedonia. Also, this fish species is regarded as new host for Trichodina sp. in Macedonian waters.

Trichodinids are usually found on the skin, fins and gills of marine and freshwater fish. The presence of a ring of interlocking cytoskeletal denticles is their characteristic and it provide cell support and adhesion to surfaces including fish tissue. There are two surfaces, one of them is cytostome which is on the part that faces away from the host (oral surface) and the other is aboral surface, attaches to the skin of the host or other substrate.

Trichodinids have a simple direct life cycle. They have a single host and do not use alternation of generations or mass asexual replication of the host. Transmission occurs by direct contact between infected and uninfected hosts, and also by active swimming of trichodinids from one host to another. 
According to Abowei et al. (2011), the representatives of the genus Trichodina are uniformly ciliated protozoan parasites whose body has the shape of a plate. Trichodinids are attached to the body of the fish by special fixative apparatus - an adhesive disc. The parasite moves through the water with the help of lashes that are arranged in two rows along the edges of the upper and lower side of the body. These parasites infest the skin, gills and fins of fish, causing tissue irritation. One of the symptoms is a general impairment of fish health, anxiety, loss of appetite and dyspnea.

According to Basson and Van as (2006), trichodinids generally have a low degree of specificity to a single host. Most species are commensals, which cause little or no damage to their hosts, while many are important ecto-parasites, which, if present in large numbers, can cause serious epithelial damage to the skin and gills in fish.

According to Lom and Dykova (1992), the rapid development and direct life cycle of Trichodina sp. can be problematic in both recirculation systems and low quality water systems. Trichodinids never occur in large numbers in fish with good condition. The most sensitive are the young categories of fish aged 4 days to 1 year, compared to the older categories which do not get sick, but can be parasite carriers. Despite the natural components of the ecosystem, the presence of these ectoparasites in debilitated fish may be an indicator of deteriorating environmental conditions.

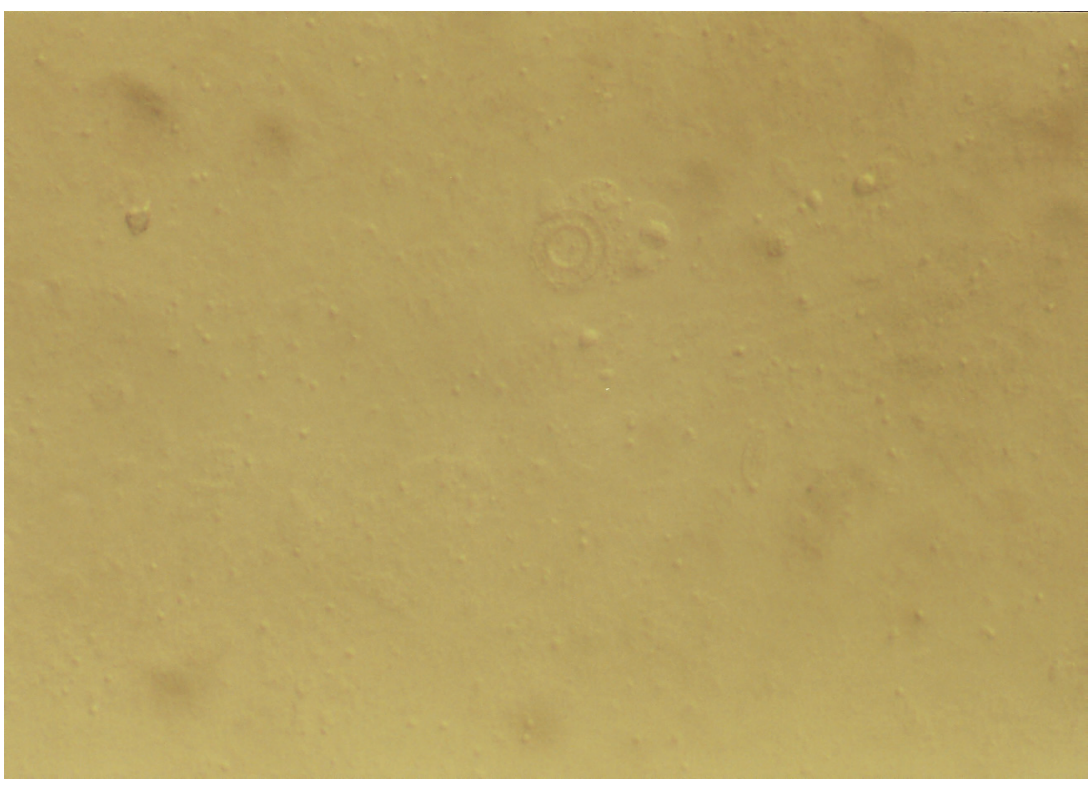

Figure 1. Trichodina sp. on gills of Ctenopharyngodon idella from fish farm Bukri 


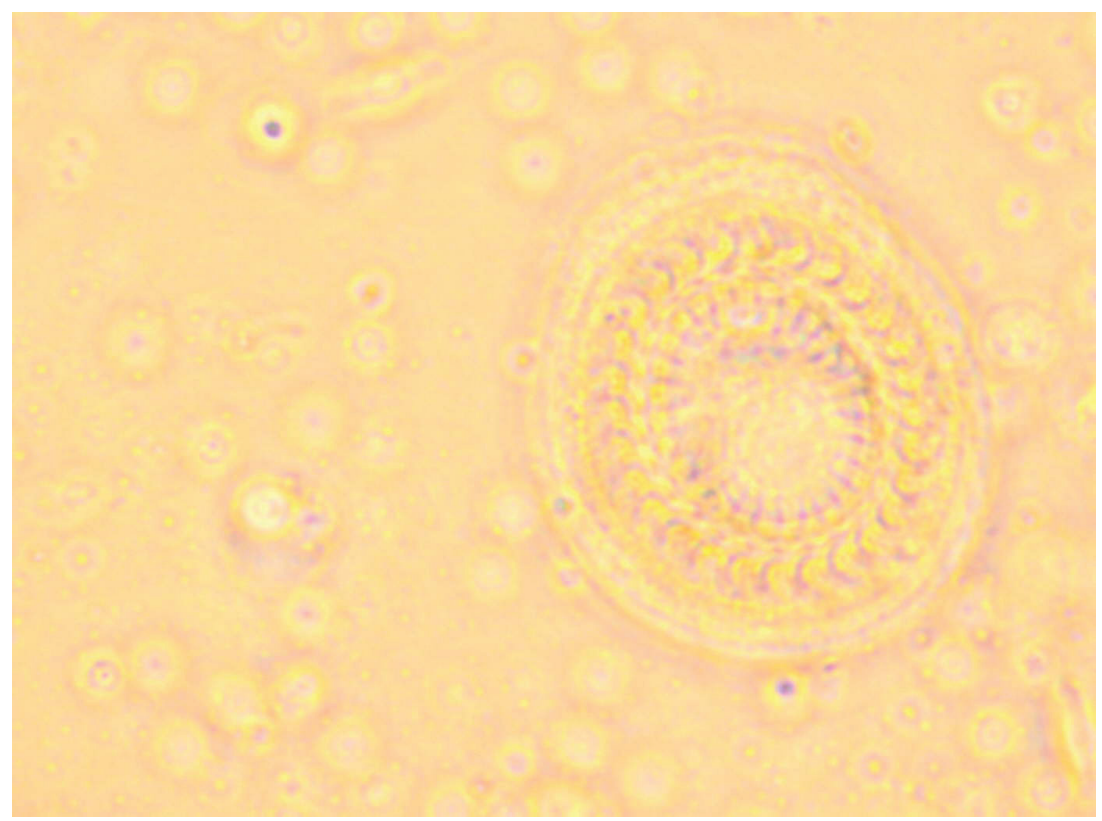

Figure 2. Trichodina sp. on liver of Cyprinus carpio from fish cage system on reservoir Gradche

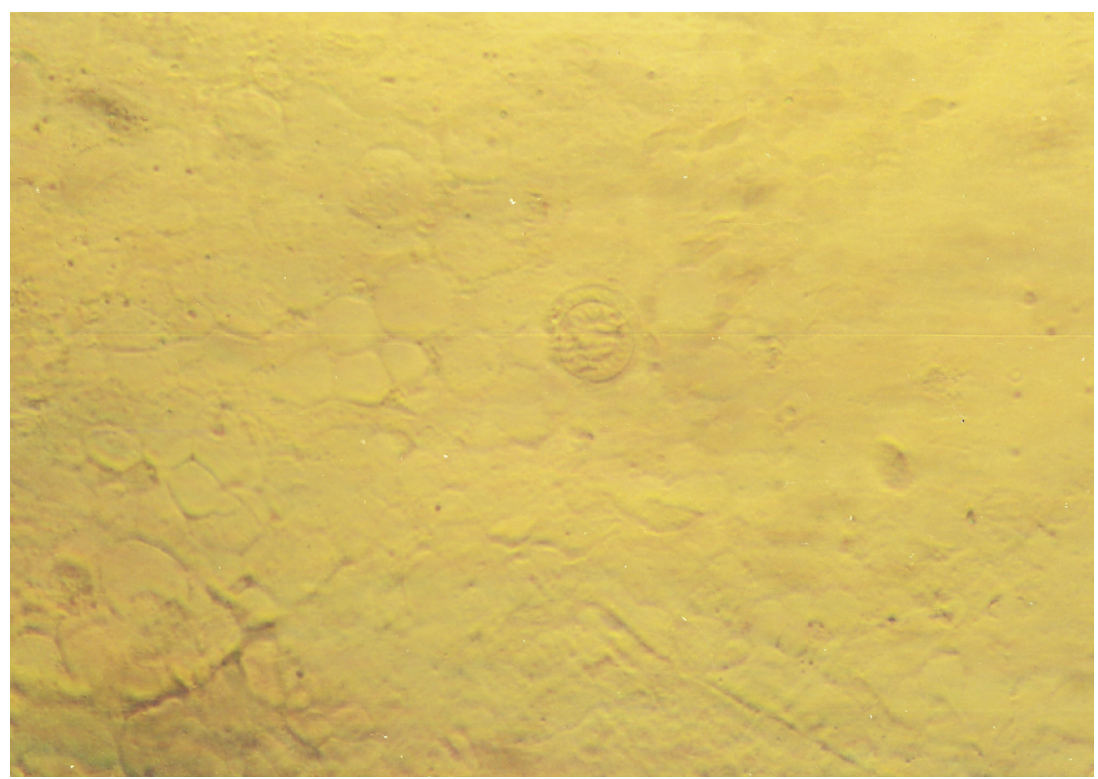

Figure 3. Trichodina sp. on fins of Ctenopharyngodon idella from fish farm Zhabeni 


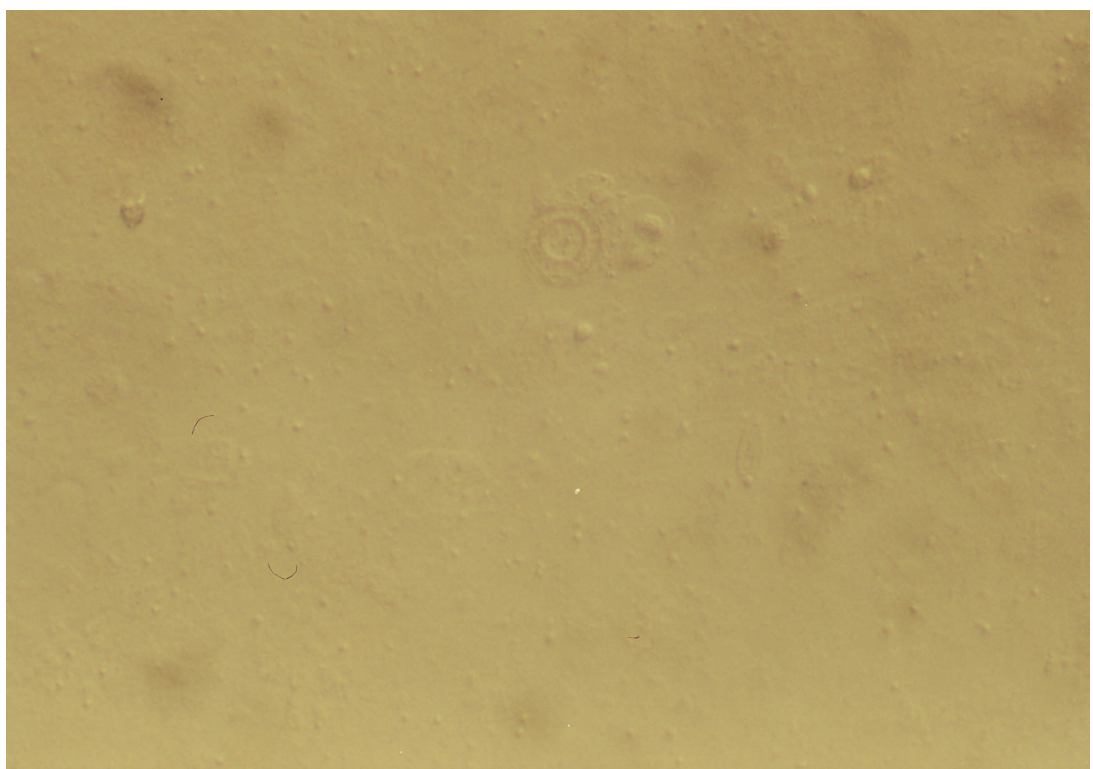

Figure 4. Trichodina sp. on gills of Ctenopharyngodon idella from fish farm Bukri

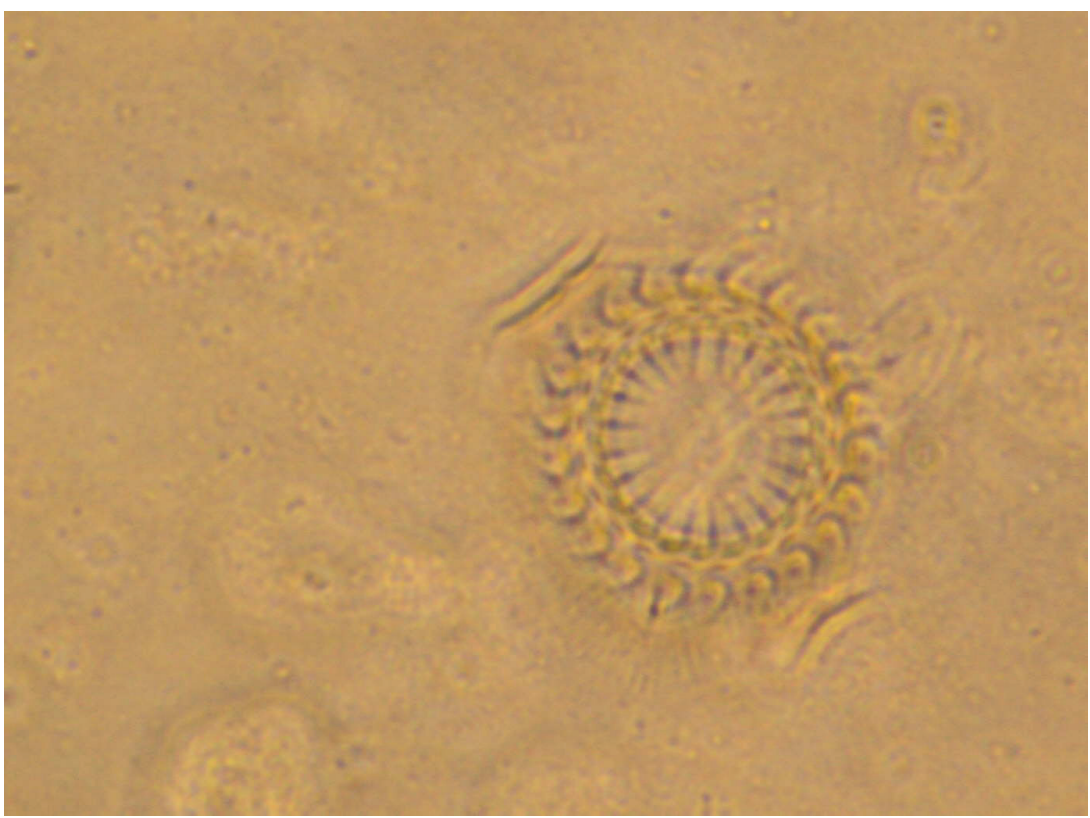

Figure 5. Trichodina sp. on gills of Cyprinus carpio from fish cage system on Globochica reservoir 
Most trichodinids are ectocommensal and they use the fish only as a substrate for attachment, while they feed on suspended bacteria. High bacterial loads provide abundant food for trichodininds, which subsequently proliferate on hosts and then cause attachment-related pathologies. According Khan (2004) and Huh et al. (2005), most trichodinids are not pathogens, but when the relationship host/parasite/environment is misbalanced by nutritional deficiency, poor water quality, infectious and/or parasitic diseases, trichodinids may proliferate, being responsible for severe epidermal lesions and disease outbreaks.

\section{Conclusions}

The presence of this protozoan in common carp are determined throughout all seasons, but trichodins usually never occur in large numbers to seriously damage the health of the host, if other, non-specific factors do not act at the same time.

Our findings of Trichodina sp. in grass carp in the present study is considered as the first record in Macedonia. Also, this fish species is regarded as new host for Trichodina sp. in Macedonian waters.

Total, the prevalence with Trichodina sp. in common carp was $35.67 \%$, while the mean intensity 4.56. The prevalence with Trichodina sp. in common carp by season was as following: spring $-11.82 \%$, summer $-3.44 \%$, autumn $-7.85 \%$, winter $-7.05 \%$, while the mean intensity was: spring -4.55 ; summer -4.67 ; autumn -4.40 ; winter -4.40 .

The prevalence with Trichodina sp. in grass carp was $11.84 \%$, while the mean intensity 7.56 .

Clinical signs of Trichodiniasis in fish are slow movement, loss of appetite, black coloration, necrosis and ulcer on different parts of the body and excessive accumulation of mucous in gill filaments. If the trichodinids occur in aquaculture, it is usually indicates eutrophication or poor water quality.

\section{References}

Abowei, J.F.N., Briyai, O.F., Bassey, S.E. (2011). A Review of Some Basic Parasite Diseases in Culture Fisheries Flagellids, Dinoflagellides and Ichthyophthriasis, Ichtyobodiasis, Coccidiosis Trichodiniasis, Heminthiasis, Hirudinea Infestation, Crustacean Parsite and Ciliates. British Journal of Pharmacology and Toxicology, 2 (5), 213-226.

Ali, N.M., Salih, N.E., Abdul-Ameer, K.N. (1988). Protozoa and crustacea infesting three species of carp raised in ponds in Iraq. Journal of Biological Science Research, 19 (2), 387-394.

Asmat, G. (2004). First record of Trichodina diaptomi (Dogiel, 1940) Basson and Van As, 1991, T. heterodentata Duncan, 1977 and T. oligocotti (Lom, 1970) (Ciliophora: Trichodinidae) from Indian fishes. Pakistan Journal of Biological Sciences, 7 (12), 2066-2071.

Basson, L., Van As, J.G. (2006). Trichodinidae and other ciliophorans (Phylum Ciliophora). In: P.T.K. Woo (ed.), Fish diseases and disorders. Protozoan and metazoan infections, Vol. 1 (pp. 154-182). Wallingford, UK: CAB International.

Bozorgnia, A., Youssefi, M.R., Barzegar, M., Hosseinifard, S.M., Ebrahimpour, S. (2012). Biodiversity of Parasites of Fishes in Gheshlagh (Vahdat) Reservoir, Kurdistan Province, Iran. World Journal of Fish and Marine Sciences, 4 (3), 249-253.

Bush, A.O., Lafferty, K.D., Lotz, J.M., Shostak, A.W. (1997). Parasitology meets ecology on its own terms: Margolis et al. Revisited. Journal of Parasitology, 83, 575-583. 
Cakić, P. (1992). Paraziti riba u vodama Sjeničko-Pešterske visoravni i mogučnosti njihovog suzbijanja. Doktorska disertacija. Beogradu, Srbija: Veterinarski fakultet Univerziteta u Beogradu.

Cengizler, İ., Necdet, A., Aysel, S., Argun, A.O., Ercüment, G. (2001). Ecto-Endo Parasite Investigation on Mirror Carp (Cyprinus carpio L., 1758) Captured From the River Seyhan, Turkey. E.U. Journal of Fisheries \& Aquatic Sciences, 18 (1-2), 87-90.

Hristovski, N., Stojanovski, S., Baker, R.A., Petrovic, Z., Rusinek, O., Čakić, P. (2006). Parasite fauna of the fishes from Lake Prespa and life cycle of economically important and most frequently found parasite species. Bitola, Macedonia: Faculty of biotechnical sciences.

Hristovski, N., Stojanovski, S., Talevski, T., Blažeković-Dimovska, D. (2012). The fish parasite fauna and the fish of Lake Prespa. Bitola. Macedonia: National and University library. University "St. Kliment Ohridski".

Huh, M.D., Thomas, C.D., Udomkusonsri, P., Noga, E.J. (2005). Epidemic trichodinosis associated with severe epidermal hyperplasia in largemouth bass, Micropterus salmoides, from North Carolina, USA. Journal of Wildlife Diseases, 41 (3), 647- 653.

Khan, R.A. (2004). Disease outbreaks and mass mortality in cultured Atlantic cod, Gadus morhua L., associated with Trichodina murmanica (Ciliophora). Journal of Fish Diseases, 27 (3), 181-184.

Lazar, M. (2009). Morphological basis of sweet water fish diseases from fish farms. Doctoral thesis, Iasi, Romania: University of agricultural sciences and veterinary medicine „Ion Ionescu De La Brad”.

Lom, J. (1995). Trichodinidae and other ciliates (phylum Ciliophora). In: P.T.K. Woo (ed.), Fish diseases and disorders, Vol.: Protozoan and metazoan infections (pp. 229-262). Wallingford: CAB International.

Lom, J., Dykova, I. (1992). Protozoan parasites of fishes. Amsterdam and London: Elsevier.

Mansoor, N.T., Al-Shaikh, S.M.J. (2010). Protozoans infection of Cyprinus carpio L. from Bab Al-Muatham fish markets, Baghdad City. Iraqi Journal of Veterinary Medicine, 34 (1).

Marcotegui, P.S., Montes, M.M., Barneche, J., Ferrari, W., Martorelli, S. (2018). Geometric morphometric on a new species of Trichodinidae. A tool to discriminate trichodinid species combined with traditional morphology and molecular analysis. International Journal for Parasitology. Parasites and Wildlife, 7 (2), 228-236.

Martins, M., Ghiraldelli, L. (2008). Trichodina magna Van As and Basson, 1989 (Ciliophora: Peritrichia) from cultured Nile tilapia in the state of Santa Catarina, Brazil. Brazilian Journal of Biology, 68 (1), $169-172$.

Martins, M.L., Cardoso, L., Marchiori, N., Benites de Pádua, S. (2015). Protozoan infections in farmed fish from Brazil: diagnosis and pathogenesis. Revista Brasileira de Parasitologia Veterinária, 24, 1-20.

Ondračková, M., Valová, Z., Kortan, J., Vojtek, L., Adámek, Z. (2012). Consequent effects of the great cormorant (Phalacrocorax carbo sinensis) predation on parasite infection and body condition of common carp (Cyprinus carpio). Parasitological Research, 110 (4), 1487-1493.

Radu, D., Oprea, L., Nicolae, C.G. (2008). Comparative analyses concerning parasitic diversity of common carp and koi carp. Zootehnie si Biotehnologii, 41 (2).

Subasinghe, R.P. (1992). Hatchery diseases of freshwater fish in Sri Lanka. In: M. Shariff, R.P. Subasinghe, J.R. Arthur (ed.), Diseases in Asian Aquaculture 1. Philippines: Asian Fisheries Society.

Tang, F.H., Zhao, Y.J. (2011). Study of trichodinids (Protozoa, Ciliophora) parasitic on gills of freshwater fishes from Chongqing, China, and identification of a new species, Trichodina cyprinocola sp. nov. African Journal of Microbiology Research, 5 (26), 5523-5527.

Tang, F.H., Zhao, Y.J. (2012). Two trichodinids of Paratrichodina (Ciliophora, Peritrichida, Trichodinidae) infecting gills of Ietalurus punetaus from Chongqing, China. African Journal of Microbiology Research, 6 (9), 2145-2149. 
Tantry, T.A., Nazir, R., Chishti, M.Z., Ahmad, F., Dar, G.H., Dar, J.S. (2016). A report on the incidence of Trichodina heterodentata from fishes of Jammu, J\&K India. Journal of Parasitic Diseases, 40 (2), 524-527.

Tomec, M., Hacmanjek, M., Teskeredžić, Z., Teskeredžić, E., Čož-Rakovac, R. (1995). Kvaliteta vode i ektoparazitarne bolesti ciprinidnih riba. Ribarstvo, 53 (4), 129-139.

Valić, D., Kapetanović, D., Kurtović, B., Teskeredžić, E. (2005). Paraziti riba rijeke Krke. Simpozij “Rijeka Krka i Nacinalni park Krka” (pp. 57-58).

Žitnan, R., Kiškaroly, M., Čanković, M. (1969). Epizootiološki odnosi parazitoza ekonomski značajnih i bijelih riba u jednom šaranskom gazdinstvu u BiH. Ichthyologia, 1 (1), 99-108.

Cite as: Blazhekovikj-Dimovska, D., Stojanovski, S. (2020). Ectoparasitic species of the genus Trichodina (Ciliophora: Peritrichida) parasitizing macedonian freshwater fish. Acta Biologica, 27, 11-20. DOI: 10.18276/ab.2020.27-02. 